\title{
COMBAT SURFERS: A NARRATIVE STUDY OF VETERANS, SURFING, AND WAR TRAUMA
}

\author{
SURFISTAS DE COMBATE: UM ESTUDO NARRATIVO DE VETERANOS, \\ SURFING E TRAUMA DE GUERRA
}

\author{
SURFISTAS DE COMBATE: UN ESTUDIO NARRATIVO DE VETERANOS, \\ SURFING Y TRAUMA DE GUERRA
}

Nick Caddick*, Brett Smith**

\section{Keywords:}

Narrative.

Veterans.

Trauma.

Surfing.

Health

Palavras chave: Narrativa.

Veteranos.

Trauma.

Surf.

Saúde

Palabras clave: Narrativa.

Veteranos.

Trauma.

Surf.

Salud
Abstract: We use narrative inquiry to illustrate the complex lives and experiences of combat veterans who go surfing to deal with the traumatic aftermath of war. The stories we collected reveal the rich and varied qualities of veterans' surfing experiences. These stories are several things at once. They are personal, revealing the body in motion as it negotiates the natural environment. They are social and cultural, shaped as they are by dominant societal narratives about veterans and masculinity. And, importantly, they are also actors, shaping the ways in which veterans experience themselves, each other, and the world around them.

Resumo: Usamos a investigação narrativa para ilustrar as vidas complexas e experiências de veteranos de combate que vão surfar para lidar com as conseqüências traumáticas da guerra. As histórias que coletamos revelam as qualidades ricas e variadas das experiências de surf dos veteranos. Essas histórias são várias coisas ao mesmo tempo. Eles são pessoais, revelando o corpo em movimento como ele negocia o ambiente natural. Eles são sociais e culturais, moldados como eles são por narrativas societal dominantes sobre veteranos e masculinidade. E, o mais importante, eles também são atores, moldando as maneiras pelas quais os veteranos experimentam a si mesmos, uns aos outros e ao mundo à sua volta.

Resumen: Utilizamos la investigación narrativa para ilustrar las complejas vidas y experiencias de los veteranos de combate que van a surfear para tratar las consecuencias traumáticas de la guerra. Las historias que recopilamos revelan las cualidades ricas y variadas de las experiencias de surf de los veteranos. Estas historias son varias cosas a la vez. Son personales, revelando el cuerpo en movimiento mientras que negocia el ambiente natural. Son sociales y culturales, conformados por las narrativas dominantes de la sociedad sobre los veteranos y la masculinidad. Y, lo que es más importante, también son actores, moldeando las maneras en que los veteranos se experimentan a sí mismos, entre ellos, y el mundo que los rodea.
*Anglia Ruskin University. Cambridge, United Kingdom.

E-mail: nick.caddick@anglia.ac.uk

${ }^{*}$ University of Birmingham. Birmingham, United Kingdom. E-mail: b.smith.4@bham.ac.uk

Recebido em: 18-09-2016 Aprovado em: 12-02-2017 (c) (1) (8) Licence 


\section{INTRODUCTION}

Stories about veterans of military combat are a contested genre. After more than a decade of unpopular wars in Iraq and Afghanistan, societal attention has turned to the legacies of these conflicts, including how to support veterans in making the transition from the military to civilian life (COOPER et al. ${ }^{1}$, in press). Various cultural narratives circulating in the press, among veterans' charities, in government, and among veterans themselves make competing claims to tell the truth about veterans' lives and experiences post-conflict. In Europe and the US, heroic narratives abound, celebrating the sacrifices and achievements veterans have made on behalf of their country (MCCARTNEY, 2011; ZIMBARDO; BRECKENRIDGE; MOGHADDAM, 2015). These are juxtaposed with, or sometimes combined with, stories of veterans as 'victims' of wartime experience or of government and military failings (MCCARTNEY, 2011). Less common since Vietnam, but also part of the narrative spaces they inhabit, are stories of veterans as 'villains'; as shameful perpetrators of violence and abuse, such as the abusing of war prisoners in Iraq (MCCARTNEY, 2011).

One genre of contested stories are those of veterans experiencing post-traumatic stress disorder (PTSD) and the wide range of available treatments for them, many provided by an increasingly large and competitive network of veterans' charities (MACMANUS; WESSELY, 2013). One recent article in The Times (a UK national newspaper) accuses military charities of "inflating the PTSD problem" (HAYNES, 2016) in order to inspire donations now that they can no longer rely on a steady stream of images of injured veterans returning from the front line. This is despite researchers' claims that rates of PTSD in the British military remain low, at around 7\% among infantry combat roles (FEAR et al., 2010). The article also repeats earlier suggestions (see MACMANUS; WESSLEY, 2013) that veterans' charities now provide a very large and confusing array of treatments for PTSD, leaving many veterans unsure where to turn for help. Amidst this debate, military charities are coming under increasing pressure to demonstrate the effectiveness of their proposed solutions to veterans' mental health problems, and to present the underpinning evidence supporting new or novel forms of therapy (ASHCROFT, 2014).

Into this contested space, we present the stories of one group of combat veterans using surfing as a way of dealing with the traumatic aftermath of their experiences in combat. These stories are derived from a narrative research project conducted between 2011 and 2014 with a veterans' surfing charity based in Cornwall, UK (CADDICK; PHOENIX; SMITH, 2015; CADDICK; SMITH; PHOENIX, 2015a, 2015b). The project began as a practical way of conceptualising and exploring the notion of the "Blue Gym"; a developing approach to promoting health and well-being through being active in natural water environments, from swimming or surfing in the sea, to kayaking and fishing in lakes and rivers, or simply walking along the coast (DEPLEDGE; BIRD, 2009; SMITH; SPARKES, 2012). As Smith and Sparkes (2012, p. 343) suggested, "[...] this moves traditional notions of the gym as an indoor, machine-filled contained physical place and space to conceptualising it as part of our multisensory natural environment, city surroundings or maritime culture". The research questions we explored were (1) what effect does surfing have on the lives and well-being of combat veterans; and (2) what kinds of stories shape veterans' experiences of surfing and the "Blue Gym", how do they do this, and with what effects? 


\section{A NARRATIVE APPROACH TO STUDYING WAR TRAUMA AND THE IMPACT OF SURFING}

Contemporary war stories often invoke the notion of post-traumatic stress disorder (PTSD) to describe the psychological and emotional consequences of traumatic experiences in combat. PTSD is used to refer to a series of 'symptoms' that some veterans experience, sometimes for years or even decades after their time in combat. These include nightmares, flashbacks, anger, anxiety and 'hyper-arousal', and a profound sense of morbid sadness. The term PTSD has become ubiquitous in society, and is frequently depicted as synonymous with the wars in Iraq and Afghanistan (PURTLE, 2016). Critics, however, have suggested that the notion of PTSD places veterans' experiences firmly within a medical framework of understanding, channelling their experiences into this narrowly defined medical category (SUMMERFIELD, 2004).

In contrast, a narrative approach seeks to put veterans' own stories and experiences at the heart of the analysis. Among the many benefits of a narrative approach is an ability to reveal the temporal, contextual, and emotional quality of people's lives and relationships (PÉREZ-SAMANIEGO; DEVÍS-DEVÍS; SPARKES; SMITH, 2011; SMITH, 2010). In addition, narrative enables us to conceive of the stories people tell as simultaneously both personal and social; whereby the storyteller is understood as a unique individual with agency but also as someone who is socially situated and whose story is shaped by the culture they inhabit (PAPATHOMAS, 2016; SMITH, 2010). Importantly, as Frank (2010) suggested, narratives are also more than simply passive representations of people's lives; they do things. Narratives act on, in, and for people in ways that can have both good and dangerous consequences for their lives. Narratives act on people in the sense that they constitute certain emotions, beliefs, and practices as appropriate in the context of a particular story, whereas others are constituted as inappropriate. For example, narratives act by making certain responses to illness seem more credible than others (SMITH; SPARKES, 2011), or by getting people to care about their health and calling on them to adopt certain health promoting practices (SMITH, 2013).

\section{METHODS}

Participants included 15 combat veterans who belonged to a surfing charity for veterans based in the UK, and one former member of the civilian emergency services who was also a member of the charity. Following our previous definition (see CADDICK; SMITH, 2014, p. 16), the term 'combat veteran' here refers to "any current or former member of the military who has previously deployed to a warzone and been exposed to the risks of combat". Eleven out of the 16 participants had been officially diagnosed with PTSD. Being officially diagnosed was not a requirement for inclusion in our study given that PTSD is a contested category of disorder and could arguably be viewed as the medicalization of veterans' suffering (SUMMERFIELD, 2004). Regardless of diagnosis, however, all of the participants referred to themselves as living with PTSD. All the participants were men and ranged in age between 27 and 60. Collectively, they possessed a wide range of combat experiences, including in Northern Ireland, the Falklands, Bosnia, the first Gulf War, and the most recent wars in Iraq and Afghanistan. 


\subsection{Data Collection}

After providing informed consent, all participants were initially involved in a semistructured life-history interview with the first author (N.C.). The interviews were conducted either in the participants' home or in the charity's headquarters. Follow-up interviews were later conducted with half of the participants in order to collect additional information, or to flesh out the detail of their stories when needed. The aim of the interviews was to collect rich, multilayered stories from the participants about how they had lived their lives over time. To facilitate this, a semi-structured interview guide was used flexibly throughout in order to stimulate storied reflection on important topics. Examples of questions included 'What has your experience of surfing been like?' and 'What role does surfing play in your life?' The interviews numbered 24 in total and lasted between one and four hours each.

Participant observation was also used to supplement and extend the interview data (SPARKES; SMITH 2014). This involved the first author learning about the participants' lives by observing and participating in their daily activities across a number of settings including (1) at 18 of the charity's surf camp sessions (held twice-weekly on a Wednesday and a Friday, (2) during informal meetings at the charity's headquarters (a drop-in centre with sofas and tea/coffee where the veterans often met together socially), and (3) during three 'residential weeks' where the veterans lived together in shared accommodation, participating in a range of daily activities including yoga, coastal walking, surfing, and meditation sessions. Following a period of observation, the first author used field-notes to document the findings, resulting in approximately 90 hours of observational data. Overall, data collection for this study spanned a period of 1 year and 6 months, with interviews and participant observations beginning in April 2012 and conducted at routine intervals until September 2013.

\subsection{Analysis}

A dialogical narrative analysis (DNA; see FRANK, 2010) was used to make sense of both the interview and observational data. Crucially, a DNA involves studying the effects that stories as 'actors' have for and on people's lives. The analyst first considers what type of story is being told and how that story is structured (as in a structural analysis). He or she then seeks to understand "the mirroring between what is told in the story - the story's content - and what happens as a result of telling that story - its effects" (FRANK, 2010, p. 71-72). Importantly, Frank (2010, p. 21) rejects a purely 'mimetic' understanding of narrative whereby "[...] stories imitate life that has already happened and now is being represented in the story". Rather, stories also shape what becomes experience. This being said, we readily acknowledge that people's everyday experience is of a physical world in which their embodied actions - their fleshy, physical, and sentient capabilities - have the power to influence their life. Accordingly, as part of our analysis we desired to hold onto a sense of participants' immediate bodily engagement with the world, whilst simultaneously understanding the storied quality of their lives and experiences.

The analysis was conducted as follows. The first author began by immersing himself in the data, reading and closely re-reading the interview transcripts and field-notes. As part of this process, a number of the veterans' stories that seemed to speak to the research questions were selected for analytical attention. The data were then annotated with conceptual comments 
which included, for example, notes on the type of stories being told and how they were narrated. Care was taken during this process not to "over-code" the data, and thereby fragmenting the story rather than appreciating it as a whole (see CADDICK, 2016; SMITH, 2016a, b). Next a key step in the analytical process involved interrogating the data via a series of 'dialogical questions' (see FRANK, 2010), which were asked in order to illuminate the effects that stories were having on the veterans' lives. Such questions included, for example, how do the veterans' stories connect/affiliate them into groups, how do their stories help them create and sustain an identity, and what is at stake for the veteran in the telling of a particular story?

\title{
4 FINDINGS
}

In what follows, we present three types of stories which collectively shaped the veterans' experiences within the charity. First are body stories, which illustrate the physical sensations of surfing and interacting with nature which were crucial to how surfing influenced the veterans' lives. Second are relational stories which describe how the veterans formed a collective narrative identity with important implications for their well-being and post-trauma lives. Third are gendered stories which highlight the way in which veterans responded to their suffering as men discussing their problems within the cultural constraints of acceptable versions of masculinity. We finish by discussing the practical and social implications of this research.

\subsection{Stories of the Surfing Body: respite rrom PTSD}

In stark contrast to the exhausting cycle of nightmares, flashbacks, and other traumatic symptoms which characterised their everyday lives, each of the veterans discussed how surfing enabled them to push their troubles into the background and experience a feeling of respite from their suffering. The veterans were very consistent in their description of this phenomenon, using terms like "freedom" to evoke the sensations that surfing produced in their bodies. The following quote from Matthew (all names are pseudonyms) is illustrative:

\begin{abstract}
It frees you up. It's freedom for those two or three hours, kind of like a bit of respite. It takes your mind off it. Just leave all that away somewhere on the beach and then, we'll deal with that later. But for now, when we're surfing, we're going to have a laugh. And there's not a lot you can do to not have a laugh; it's kind of the antidote to PTSD in a way. You know, get your wetsuit on, go for a paddle, ride a wave, and it's like PTSD doesn't exist for that short time, which is all good in my book.
\end{abstract}

Respite, as articulated by the participants, was a positive feeling of release from everyday struggles associated with PTSD. The notion of respite conveys the temporary absence of trauma-related thoughts and feelings, bringing about a much-needed relief from suffering. Respite allowed the veterans to forget about PTSD, or to place it on hold, while they focused on enjoying the surfing experience. Their descriptions resonated with the phenomenon psychologists refer to as flow (CSIKSZENTMIHALYI, 2002), whereby one becomes absorbed or immersed in an activity to the exclusion of all other thoughts and emotions, resulting in a deeply rewarding experience.

One crucial effect of surfing and stories of surfing as respite was that they helped veterans to hold off the chaos that can sometimes ensue from chronic suffering (FRANK, 2013; SMITH; SPARKES, 2011). As Frank (2013) explained, chaos is an 'anti-narrative' whereby the 
teller of the story imagines life never getting better, and life is swallowed up by the hopelessness of chronic suffering. The veterans' stories revealed how embodied sensations of surfing helped to constitute this effect:

The feel-good effect it has is fantastic, really, for me. I mean, I just come out of there [sea], one, I'm pretty knackered, and two, you got that feeling of just like, "Ahhhh, God," you know, "that was so good!" But that feeling of-it's not just being in the water, it's like a washing away [of PTSD], you know, with the water. And especially when it gets a bit rough and you get turned over by the waves a few times, it feels like it's just pummeling it out of you or just washing it out of your system a little bit. (LARRY)

Larry's comments reveal that going surfing and experiencing respite provided the veterans with a positive boost to their well-being. Also evident was the way in which being physically immersed in the ocean environment was an intrinsic feature of the emotional benefits derived from surfing. Indeed, the body's haptic connection (SPARKES, 2016) with the ocean was strongly emphasized and was portrayed by the veterans as charged with emotion; for example, in feeling their troubles being "pummeled out" by the force of the waves. Moreover, stories of surfing as respite provided the veterans with a template - the narrative resources - to articulate the "freeing" feelings associated with surfing. These feelings did not straightforwardly emerge from within the veterans' individual bodies but came to be named and experienced as "freedom" through hearing and telling respite stories. As Burkitt (2014), and Smith, Bundon and Best (2016) suggested, the feelings themselves are deepened, extended, and restructured by language and stories.

\subsection{Relational stories: narrating a collective identity}

the veterans in this study described a sense of isolation which characterised much of their post-trauma lives. Their social world shrank leaving them enclosed and vulnerable to intensified feelings of psychological and emotional distress. Within the context of the charity, however, the veterans all told a strongly relational narrative which helped to bind them together into a community:

It's about pulling broken elements of a community together to form a tighter one than the community had in the first place. It's that bond that we've all got that, it just reinforces that you're not on your own and there is that support network - the net that's meant to catch you that you've all fallen through so far - you end up here, and it stops you falling any further. And you kind of make new friends which are slightly bonkers in various ways, but nonetheless - they're still family to me. It's about bolstering each other up and making sure that we're all alright, which I don't think you know, mainstream societies or communities have got any idea about. It's only that kind of ex-forces - those guys and girls who have done the trigger time and crawled around and bled and got beaten senseless by stuff - that's the bond, and that's what people just recognise instantly, just by kind of - the way they're holding themselves. It's like an impenetrable force-field that once you're inside, you know you're alright. Yeah, that's the kind of binding element to [charity name] - it's that band of brothers thing - it doesn't matter, like, when you're in the army, you take the piss out the RAF [Royal Air Force] or the Navy or the Marines or whatever, and you still do that here but it really doesn't matter - because if you're walking through that door then you're one of us. (MATTHEW) 
The above comments resonate with Richardson's (1990) description of a 'collective story'; binding the veterans together emotionally and gathering up their individual stories into a shared narrative. The collective story told by the group consists of veterans coming together and supporting each other in dealing with the problems associated with life after war. The story emphasises a mutual identification with those who share similar experiences and a shared concern for others who are suffering. The story - in terms of its tacit, unspoken plotline - might be summarised as follows: "We have all witnessed terrible events and we all experience PTSD. We are all suffering, but now we are no longer alone. We understand and know each other's suffering and we support each other. We stick together and help each other - just like we did in the forces."

Highlighted also in this story is the intensity of the bonds between veterans, described in terms such as 'family' or a 'band of brothers'. The story creates a strong emotional and ethical commitment to support and protect the well-being of other 'family' members. The collective story thereby performs the work of narrative identifying (FRANK, 2010); it allows personal identities to form within the collective identity. Similar to processes of military socialisation, whereby individual identity is derived from one's place in the organisation (HOCKEY, 1986), the veterans created and sustained their identity as combat veterans through interacting with the group and through enacting the collective story. Furthermore, the collective story is contrasted with certain aspects of 'mainstream' societies or communities which are portrayed as unaware of the issues facing veterans and, potentially, unable to offer appropriate support. In this way, the collective story connects others who share the status of 'veteran' and 'PTSD sufferer' and disconnects the generalised 'civilian other' who lacks the experience of suffering that binds the veterans together.

The collective story was enacted in the group environment through a series of actions, gestures, and ways of relating to others within the group. One of the key components of the story was the sense of camaraderie shared between the veterans. This consisted of strong interpersonal bonds between the veterans that mirrored relationships they held with comrades in the military (GREEN et al., 2010). For the veterans, these relationships were based on trust, friendship and mutual rapport. They were often considered deeper than relationships with civilians in their lives. Such bonding with other veterans seemed to satisfy a desire for camaraderie that civilian life had been unable to fulfil. There was a particular interpersonal style - known to the veterans as "black humour" - which cultivated and sustained their sense of camaraderie. This was a style of humour that the veterans used to make light of their predicament, and is commonly practiced in the Armed Forces (HOCKEY, 1986). An example occurred during a residential week on 16 April 2012 and was recorded in the following field-note:

\footnotetext{
This afternoon I was standing on the beach with the guys waiting to go surfing. With our boards, we formed a half-circle round the instructor who was about to lead us through some warm-up drills. 'Any injuries I should know about?' the instructor called out before we began. 'Yeah', replied one of the guys, 'injured minds!', sending everybody into fits of laughter. Shortly afterwards the guys laughed and joked their way toward the waters' edge, ready for surfing and in high spirits.
}

Other elements of the collective story included a feeling of acceptance and belonging amongst other group members, a sense that their problems were 'normalised' or 'legitimated' by being around others who shared their suffering, and a tacit, embodied connection which came with not having to explain one's suffering to others, yet instantly feeling understood by them. 
Each of these elements of the collective story enabled the veterans to experience a deeper connection to others; something which forms a key element of psychological wellbeing (RYFF; SINGER, 1998). Likewise, the collective story also fostered a reciprocal sense of responsibility among group members, which mirrored the military ethos of 'looking out for each other'. An example occurred on 17 August 2012 following one of the charity's weekly surf camps, and was recorded in the following field-note:

On the way back from the beach, I joined the group leader (also a veteran) as he stopped by the home of one guys to check up on him. This veteran had gone 'under the radar'. This means he is not answering his phone and no-one has seen him for a while. Waiting at his door, I asked the group leader 'Is this what you do when someone goes under the radar?' ... 'It's what we have to do', he replied, 'We have to do this to make sure they're ok'.

\subsection{Gendered storytelling: the dynamics of masculinity}

As several scholars have argued (e.g., CONNELL; MESSERSCHMIDT, 2005; GREEN et al., 2010; HIGATE, 2003), masculinity is something that is performed or enacted, rather than something men inherently possess. It is something they do, not something they are. In telling stories about their lives, men perform a certain kind of masculinity by constructing an image of themselves they want others to perceive. Their performances are shaped and constrained by cultural norms of gender and what acceptable versions of masculinity look like (AHLSEN et al., 2013). Within military institutions, a particular form of (hyper)-masculinity is valorised and privileged above other forms. 'Military masculinity' is traditionally performed through displays of strength and self-reliance, showing stoicism in the face of physical and emotional hardship, emphasising homosociability (that is, heterosexual male bonding and friendship), and being action-oriented and doing things (HIGATE, 2003; HOCKEY, 1986). For the veterans in this study, these ways of being masculine became inscribed in their bodies over time, operating prereflectively and naturally to shape how they experienced the world (BROWN, 2006), and how later they handled the emotional distress associated with PTSD. The following quote from Lewis depicts the influence of masculine performances on his response to suffering:

$N C$ : So why do you think it maybe took a while to admit to yourself then that things were going wrong?

Lewis: Erm - you're a bloke and you're stubborn and you got like, male pride. And also the fact that I feel like I was ... I was very lucky compared to other people out in Iraq. I thought you had to see your mate get blown up or something like that before you had PTSD. But then other people l've spoken to that have had PTSD in the past have said you don't have to sort of be ... having your mates blown up or anything, it can just be the pure stress of going out on patrol, getting shot at. The adrenaline's up and down and your fear factor's up and down and just the pure fact that you're scared or whatever and just - doing it all the time. So with all that, yeah - ok, you might have a problem. But it's just the pure fact that I just thought I hadn't had as much action as some of the other people that have got PTSD. I was lucky compared to some of the other people and so I just tried to ignore it. It's like the old military sort of ways; just man-up and get on with it.

The performance of military masculinity is exemplified in Lewis's "man-up and get on with it" comment. Given that emotional distress is typically constructed as 'weak' and 'feminine' within a military masculine context, experiencing the symptoms of PTSD was deeply uncomfortable for 
the veterans, conflicting with their sense of themselves as manly men and presenting them with evidence that they were not simply "getting on with it". Consequently, the veterans often allowed PTSD to linger, unrecognised or denied, suffering increasing damage both to their own mental wellbeing and that of the family members they lived with.

The response of denying or avoiding distress (as shown in the above comments) might be considered as the veterans' dominant or habitual response to dealing with distress, conditioned through years of military experience. Within the context of the surfing charity, however, the veterans were able to embrace a different response to suffering; one that enabled them to admit to the problems they were experiencing within a masculine frame of reference. The following comments illustrate this alternative response and the key role that surfing played in facilitating it:

\begin{abstract}
I'm determined to stand on that surfboard. You know, one of the things that the military does - it throws challenges at you. And my civilian counterparts would most likely say 'Well, we're not sure we can do this', whereas the military attitude is 'Yeah, get on with it', and then cope with what comes up at the time - not look for the problems first, deal with the problems as they arise. I've got to stand on that bloody thing! l've got to and it's an immediate short term goal that I can achieve and I'm going to achieve it. And that in itself then helps with the PTSD because you've done something. You haven't sat back sucking your thumb, crying into your beer, pissing and moaning about how bad life is, you've gone out and you've done something. And in my case, something completely different to what l've ever done before. And you can see l'm grinning when I talk about it - it says it all really. You go away with a grin, a good belly laugh!
\end{abstract}

Illustrating the complexity of military masculinities (HIGATE, 2003), the dominant response of "man-up and get on with it" could be reconstructed as a way of dealing with PTSD and improving wellbeing, for example by doing things to counteract PTSD rather than passively denying or 'giving in' to it. In the social context of the charity, maintaining a denial of PTSD as simply 'getting on with it' could be construed as a refusal to come to terms with one's suffering, and hence, paradoxically, not getting on with it. Among these veterans, masculine worth and status was portrayed not by denying suffering, but through actively dealing with it; through fighting it. Highlighting how masculinity is performed in different situations, the meaning of "getting on with it" in the group thus shifted from denying one's suffering to fighting it and facing it head on, like a man. For the veterans, this meant actively doing things to cultivate wellbeing, such as attending surf camps and residential weeks, talking to other veterans and engaging in meditation and relaxation sessions. Accordingly, by negotiating the terms in which masculinity is expressed, the veterans were able to promote a positive, proactive means of addressing mental health problems and supressing stigma.

Yet despite the value of this 'proactive' approach to mental health within the subculture of the charity, veterans sometimes still found it difficult to ask for help from others. Asking for help had to be carefully negotiated in order for the veterans' to maintain their strongly gendered and militarized identities, as the following quote illustrates:

I just sort of disappeared off the map. My girlfriend contacted [the charity] and said, 'What the fuck is going on? He's disappeared, I don't know whether he's alive or dead, he's in a state - get in touch'. And then I had missed calls from several of the guys at [the charity], and ... it's hard to explain, but - as much as I knew they cared, I didn't want them to know me as a wreck - as somebody who couldn't cope. So I ignored them - it was the only way I could deal with it, because I didn't know how to explain what was going on. And it was like, l'd get the call and l'd look at it and 
I'd go 'All you got to do is say hello'. But I physically couldn't even do that. My mind wouldn't let me. I know it's a strange thing to say, but as much as I wanted to at times, I just went 'I can't do it'. Because I don't like being in a position of weakness.

Accordingly, the veterans sometimes struggled to override the dominant military masculine response of denial and self-reliance in relation to dealing with distress. Which version of masculinity would be performed - that is, which story about themselves would be told - thus depended to a large extent on the contextual and situational factors of storytelling, such as who the teller and listener were, and for what purpose the story was being told (SPARKES; SMITH, 2008).

\section{DISCUSSION}

Our research reveals the stories which shaped veterans' experiences of surfing as a way of dealing with the problems caused by traumatic combat experiences and PTSD. The narrative approach we adopted here places veterans' own life stories centre stage, set against other voices which claim to speak the truth on their behalf. For example, these veterans rejected the dominant hero-victim narratives which typically fail to capture the complex experiences of those living with the after effects of war, and which trap them in a narrative of the past (BULMER; JACKSON, 2016). Instead, they emphasised stories of comradeship and mutual connection, stories about the restorative power of the body in nature, and stories which negotiating a gendered response to suffering.

Whilst the veterans' stories claim a personal truth ("I was there, it happened like this"), these stories are never straightforwardly their own. This is because all personal stories borrow from a wider cultural menu of stories which compete for our attention and which act on us to shape our experiences (FRANK, 2010; PAPATHOMAS, 2016). For example, the veterans' drew upon a 'band of brothers' narrative about war and comradeship, and on stories of what 'real men' are supposed be like. Frank (2010) writes about stories as 'companions' in the sense that they have the capacity to take care of people. Yet, as we pointed out in our introduction, stories can also act in more dangerous ways. As Frank (2010, p. 145) put it, "Stories can be the most engaging companions but still make life dangerous precisely because they engage so thoroughly".

Following Frank (2010), we suggest that the veterans' stories acted for and on them in both good and potentially dangerous ways. Firstly, stories about surfing as a way of dealing with life post-trauma have the capacity to care for veterans by offering an alternative to the dominant medical model narrative of PTSD treatment. A medical model treats PTSD as an illness to be cured, or as some damaged portion of the mind or brain that requires fixing through therapy and/or psychopharmacology. Indeed, treatments officially approved and recommended for PTSD currently include a narrow range of talking and drug therapies, and do not encompass alternative approaches that might also assist veterans. Accompanying the medical model is a powerful narrative that acts to shape and constrain people's stories about (and experiences of) mental health problems (CARLESS; DOUGLAS, 2010). This has been termed the restitution narrative (FRANK, 2013), and follows the basic storyline of "[y]esterday I was healthy, today I'm sick, but tomorrow l'll be healthy again." Restitution, however, becomes problematic when a cure is not forthcoming. Stories about surfing as a form of respite thus helped to expand the narrative options available to veterans beyond the medical restitution narrative. 
In addition, collective stories also helped to provide a form of narrative care for veterans (BOHLMEIJER; KENYON; RANDALL, 2011). Narrative care refers to the empathic use of stories in healthcare settings. The collective story and 'band of brothers' narrative offers such care by affirming the value of peer support for veterans, and by making the support of others readily available. It also helped to foster solidarity among the group, and to 'normalise' or 'legitimise' their suffering; making the experience of PTSD itself acceptable and enabling them to overcome some of the stigma associated with mental health problems among military veterans (WALKER, 2010). Yet, as we noted above, there are dangers too. The collective story could also reinforce boundaries between veterans (who knew about suffering, who understood and could empathise), and the civilian other who simply cannot understand. Whilst fostering closer connections among veterans, the story could also become an "us and them" divider between veterans and civilians, serving to alienate these two groups further from one another.

The dynamic tensions of performing masculinity through stories further highlight how stories can be good but also dangerous. Traditional masculine stories about stoicism, selfreliance, and emotional toughness were deeply embedded in the veterans' bodies and proved difficult to shake off at times. At other times, stories about dealing with PTSD by facing one's problems like a man were emphasised, and a "positive" approach to dealing with mental health problems became possible. Which story took precedence on which occasion - and with what effects (e.g., help was sought or not sought) - became a narrative drama that played itself out within the context of the charity. The stakes of this drama were high, with a decent into chaos looming on the horizon for veterans unable to accept or receive help from other people.

In conclusion, our research illustrates the benefits of a narrative approach for understanding people's lives as simultaneously personal and social, and for honouring the nuanced and complex nature of people's lives and stories (SMITH, 2010). It also makes an original contribution to the study of veterans and mental health by adding to the emerging evidence base regarding the potential of sport and physical activity (particularly nature-based activities) for supporting veterans in the aftermath of trauma (CADDICK; SMITH, 2014). We also extend the literature(s) in narrative health psychology, and exercise and health psychology, by offering an empirical application of dialogical narrative analysis (Frank, 2010); an emerging and little utilised form of narrative analysis which shows great potential for examining how stories - as actors - have important consequences for the ways in which people live their lives. Our hope is that this paper will stimulate other researchers to experiment with this approach and to reap the benefits it can provide for understanding people's stories in new and interesting ways.

\section{REFERENCES}

AHLSEN, Birgitte; BONDEVIK, Hilde; MENGSHOEL, Anne; SOLBRÆKKE, Kari. (Un)doing gender in a rehabilitation context: A narrative analysis of gender and self in stories of chronic muscle pain. Disability \& Rehabilitation, v. 36, n. 5, p. 359-366, May 2013.

ASHCROFT; Michael. The veterans' transition review. London, Feb. 2014. Available at: $<\underline{w w w}$. veteranstransition.co.uk/vtrreport.pdf.>. Accessed on: 3 set.2016. 
BOHLMEIJER, Ernst; KENYON, Gary; RANDALL, William. Toward a narrative turn in healthcare. In: KENYON, Gary; BOHLMEIJER, Ernst; RANDALL, William. Storying Later Life. New York: Oxford University, 2011. p. 366-380.

BROWN, David. Pierre Bourdieu's 'masculine domination' thesis and the gendered body in sport and physical culture. Sociology of Sport Journal, v. 23, n. 1, p. 162-188, Jan. 2006.

BULMER, Sarah; JACKSON, David. "You do not live in my skin": Embodiment, voice, and the veteran. Critical Military Studies, v. 2, n. 1-2, p. 25-40, Jan. 2016.

BURKITT, Ian. Emotions and social relations. Thousand Oaks, CA: Sage, 2014.

CADDICK, Nick. Doing narrative analysis. In: LYONS, Evanthia; COYLE, Adrian. Analysing qualitative data in psychology. 2. ed. London: Sage, 2016. p. 222-239.

CADDICK, Nick; SMITH, Brett. The impact of sport and physical activity on the well-being of combat veterans: A systematic review. Psychology of Sport and Exercise, v. 15, n. 1, p. 9-18, Jan. 2014.

CADDICK, Nick; SMITH, Brett; PHOENIX, Cassandra. The effects of surfing and the natural environment on the well-being of combat veterans. Qualitative Health Research, v. 25, n. 1, p. 76-86, Jan. 2015a.

CADDICK, Nick; SMITH, Brett; PHOENIX, Cassandra. Male combat veterans' narratives of PTSD, masculinity, and health. Sociology of Health and IIIness, v. 37, n. 1, p. 97-111, Jan. 2015b.

CADDICK, Nick; PHOENIX, Cassandra; SMITH, Brett. Collective stories and well-being: Using a dialogical narrative approach to understand peer relationships among combat veterans experiencing PTSD. Journal of Health Psychology, v. 20, n. 3, p 286-299, Mar. 2015.

CARLESS, David; DOUGLAS, Kitrina. Sport and physical activity for mental health. Chichester: Wiley-Blackwell, 2010.

CONNELL, Raewyn W.; MESSERSCHMIDT, James. Hegemonic masculinity: Rethinking the concept. Gender \& Society, v. 19, n. 6, p. 829-859, Dec. 2005.

CSIKSZENTMIHALYI, Mihaly. Flow: The psychology of optimal experience. 2. ed. New York: Harper \& Row, 2002.

DEPLEDGE, Michael; BIRD, William. The blue gym: Health and wellbeing from our coasts. Marine Pollution Bulletin, v. 58, n. 7, p. 947-948, Jul. 2009.

FEAR, Nicola; JONES, Margaret; MURPHY, Dominic; HULL, Lisa; IVERSEN, Amy; COKER, Bolaji; WESSELY, Simon. What are the consequences of deployment to Iraq and Afghanistan on the mental health of the UK armed forces? A cohort study. The Lancet, v. 375, n. 9728, p. 1783-1797, May 2010.

FRANK, Arthur. Letting stories breathe: A socio-narratology. Chicago: University of Chicago Press, 2010.

FRANK, Arthur. The Wounded Storyteller: Body, illness and ethics. 2. ed. Chicago: University of Chicago, 2013.

GREEN, Gill; EMSLIE, Carol; O'NEILL, Dan; HUNT, Kate; WALKER, Steven. Exploring the ambiguities of masculinity in accounts of emotional distress in the military among young exservicemen. Social Science \& Medicine, v. 71, n. 8, p. 1480-1488, Oct. 2010. 
HAYNES, Deborah. Military charities accused of inflation PTSD problem. London, Sept. 2016. The Times. Available at: <http://www.thetimes.co.uk/article/military-charities-accused-of-inflatingcombat-stress-problem-snfighkmk>. Accessed on: 2 set. 2016.

HIGATE, Paul. 'Soft clerks' and 'hard civvies': Pluralizing military masculinities. In: HIGATE, Paul. Military masculinities: Identity and the state. Westport: Praeger, 2003. p. 27-42.

HOCKEY, John. Squaddies: Portrait of a Subculture. Exeter: University of Exeter, 1986.

MACMANUS, Deirdre; WESSELY, Simon. Veteran mental health services in the UK: are we heading in the right direction? Journal of Mental Health, v. 22, n. 4, p. 301-305. Aug. 2013.

MCCARTNEY, Helen. Hero, victim or villain? The public image of the British soldier and its implications for defense policy. Defense \& Security Analysis, v. 27, n. 1, p. 43-54, Mar. 2011.

PAPATHOMAS, Anthony. Narrative inquiry: From cardinal to marginal and back? In: SMITH, Brett; SPARKES, Andrew. Routledge Handbook of Qualitative Research Methods in Sport and Exercise. London: Routledge, 2016. p. 37-48.

PÉREZ-SAMANIEGO, Victor; DEVÍS-DEVIÍS, José; SMITH, Brett; SPARKES, Andrew. La investigación narrativa en la educación física y el deporte: qué es y para qué sirve. Movimento, v. 17, n. 1, p. 11-38, Jan. 2011.

PURTLE, Jonathan. Heroes' invisible wounds of war: Constructions of posttraumatic stress disorder in the text of US federal legislation. Social Science \& Medicine, v. 149, n. 1, p. 9-16. Jan. 2016.

RICHARDSON, Laurel. Writing Strategies. London: Sage, 1990.

RYFF, Carol; SINGER, Burton. The contours of positive human health. Psychological Inquiry, v. 9, n. 1, p. 1-28. Jan. 1998.

SMITH, Brett. Narrative inquiry: ongoing conversations and questions for sport and exercise psychology research. International Review of Sport and Exercise Psychology, v. 3, n. 1, p. 87-107, Feb. 2010.

SMITH, Brett. Disability, sport and men's narratives of health: A qualitative study. Health Psychology, v. 32, n. 1, p. 110-119, Jan. 2013.

SMITH, Brett. Narrative analysis. In: LYONS, Evanthia; COYLE, Adrian. Analysing qualitative data in psychology. 2. ed. London: Sage, 2016a. p. 202-221.

SMITH, Brett. Narrative analysis in sport and exercise: How can it be done? In: SMITH, Brett; SPARKES, Andrew. Routledge Handbook of Qualitative Research in Sport and Exercise. London: Routledge, 2016b. p. 260-273.

SMITH, Brett; BUNDON, Andrea; BEST, Melanie. Disability sport and activist identities: A qualitative study of narratives of activism among elite athletes' with impairment. Psychology of Sport and Exercise, v. 26, n. 5, p. 139-148, Sept. 2016.

SMITH, Brett; SPARKES, Andrew. Exploring multiple responses to a chaos narrative. Health: An Interdisciplinary Journal for the Social Study of Health, Illness and Medicine, v. 15, n. 1, p. 38-53, Jan. 2011.

SMITH, Brett; SPARKES, Andrew. Disability, sport, and physical activity: A critical review. In: WATSON, Nick; ROULSTONE, Alan; THOMAS, Carol. Routledge handbook of disability studies. London: Routledge, 2012. p. 336-347. 
SPARKES, Andrew. Researching the senses in sport and exercise. In: SMITH, Brett; SPARKES, Andrew. Routledge Handbook of Qualitative Research Methods in Sport and Exercise. London: Routledge, 2016. p. 343-354.

SPARKES, Andrew; SMITH, Brett. Men, spinal cord injury, memories and the narrative performance of pain. Disability \& Society, v. 23, n. 7, p. 679-690, Dec. 2008.

SPARKES, Andrew; SMITH, Brett. Qualitative research methods in sport, exercise \& health. From process to product. London: Routledge, 2014.

SUMMERFIELD, Derek. Cross-cultural perspectives on the medicalization of human suffering. In: ROSEN, Gerald. Posttraumatic stress disorder: Issues and controversies. Chichester: John Wiley \& Sons, 2004. p. 233-245.

WALKER, Steven. Assessing the mental health consequences of military combat in Iraq and Afghanistan: a literature review. Journal of Psychiatric and Mental Health Nursing, v. 17, n. 9, p. $790-796$, Nov. 2010.

ZIMBARDO, Philip; BRECKENRIDGE, James; MOGHADDAM, Fathali. Culture, militarism, and America's heroic future. Culture \& Psychology, v. 21, n. 4, p. 505-514, Dec. 2015. 